\title{
Fibrinolytic Activity and Antioxidant Effects of the Newly Developed Agabean Fermented of Product Produced by Bacillus sp.
}

\author{
Sung-Ryeal Kim', Min-Jeong Kim ${ }^{1,2}$, Hye-Hyeon Lee ${ }^{1,2}$, Min-Jeong Seo, ${ }^{2,3}$, Byoung-Won Kang ${ }^{2}$, \\ Woo-Hong Joo ${ }^{4}$, Jeong-Uck Park ${ }^{2}$, Eun-Ju Rhu ${ }^{5}$, Young-Hyun Hwang $^{6}$ and Yong-Kee Jeong ${ }^{1,2,3_{\star}}$ \\ ${ }^{1}$ Department of Biotechnology, Dong-A University, Busan 604-714, Korea \\ ${ }^{2}$ Medi-Farm Industrialization Research Center, Dong-A University, Busan 604-714, Korea \\ ${ }^{3}$ Department of Medical Bioscience, Dong-A University, Busan 604-714, Korea \\ ${ }^{4}$ Department of Biology, Changwon National University, Changwon 641-773, Korea \\ ${ }^{5}$ Department of Cosmetology, Han Seo University, Chung Nam 356-706, Korea \\ ${ }^{6}$ Department of Biosciences, Kyungpook National University, Chung Nam 702-701, Korea
}

Received October 6, 2010 / Accepted November 11, 2010

\begin{abstract}
In this study, fibrinolytic activities of fermented yellow agabean (FYA) and black agabean (FBA), and the antioxidation efficiencies of $70 \%$ ethanol extract of fermented yellow agabean (FYAE) and black agabean (FBAE) were investigated by selecting Bacillus sp. sm26 strain. Fibrinolytic activities of FYA and FBA were $6.38 \pm 0.5$ and $6.83 \pm 0.5 \mathrm{U} / \mathrm{ml}$, which were 1.3 and 1.4 times higher than that of FSB, respectively. With regard to total phenolic contents, FYAE and FBAE were $3.40 \pm 0.44 \mathrm{mg} / \mathrm{g}$ and $2.45 \pm 0.20 \mathrm{mg} / \mathrm{g}$ respectively, suggesting that their contents were about twice as high as that of fermented soybean extract (FSBE) used as a control. In comparison with FSBE, total protein and sugar contents of FYAE were $0.56 \pm 0.11$ and $2.41 \pm 0.48 \mathrm{mg} / \mathrm{g}$, respectively, and those of FBAE were $0.39 \pm 0.12$ and $2.72 \pm 0.63 \mathrm{mg} / \mathrm{g}$, respectively. This result suggests that FYAE was 4.7 and 1.7 times higher than FSBE, respectively. The DPPH radical scavenging activity of FBAE was $79 \%$ at $1 \mathrm{mg} / \mathrm{ml}$, which was highest among the fermented bean extracts, and was twice as high as FSBE in regards to activity. In addition, FBAE exhibited the highest reducing power at $1 \mathrm{mg} / \mathrm{ml}$, which was higher than FSBE by two-fold. With regard to lipid peroxidation, FBAE and FYAE were $93 \%$ and $80 \%$ at $1 \mathrm{mg} / \mathrm{ml}$, which were 3 and 2.5 times higher than FSBE, respectively. Of note, the hydrogen peroxide scavenging activities of FBAE and FYAE were $82 \%$ and $54 \%$ at $1 \mathrm{mg} / \mathrm{ml}$, offering activity that was 4 and 2.5 times higher than FSBE, respectively. Based on these results, the fibrinolytic activity and antioxidation efficiency of the fermented agabeans were significantly higher than other soybeans. Therefore, these studies may suggest that the functional agabeans can be a potential candidate for a natural functional food.
\end{abstract}

Key words : Fibrinolytic activity, antioxidant activity, Bacillus sp., fermented yellow agabean (FYA), fermented blackaga bean (FBA)

\section{서 론}

현대과학의 발달로 인해 건강 장수생활의 혜택이 커지면서 식품이 단지 영양공급과 기호성을 충족시키는 기본적인 목적 을 넘어서 꾸준한 일상섭취를 통하여 잠재적인 질병예방 및 치유의 능력까지 갖춘 기능성에 대한 연구가 중점적으로 이루 어지고 있다[7]. 특히 노화, 암, 뇌혈관과 심혈관계 질환 등은 free radical의 생성과 관련이 있다는 사실이 밝혀짐에 따라 항산화 효과를 가지는 식품의 섭취를 통해 노화를 지연시키고 이러한 질병을 예방, 치료하고자 하는 노력이 증가하고 있는 실정이다[15]. Free radical은 생체내의 산화적 스트레스에 의

*Corresponding author

Tel : +82-51-200-7557, Fax : +82-51-206-0848

E-mail : ykj9912@dau.ac.kr
해 생성되는데 세포 구성성분과 강하게 반응하여 세포와 조직 에 손상을 가하고 지속적인 DNA 손상을 주어 각종 질병을 유발하게 된다[9,18]. 생체는 이러한 free radical로부터 생체를 방어할 수 있는 superoxide dismutase (SOD), glutathione peroxidase (GPX), catalase (CAT), glutathione reductase, glutathione-S-transferase 등의 항산화 효소를 가지고 있으나 [1], 과도한 스트레스에 노출되어 있는 현대인에게는 더욱 효 과적이고 안전한 식이성 항산화제가 필요하다. 근래에 과일과 채소 등에 포함되어 되어있는 비타민 $\mathrm{C}$, 비타민 $\mathrm{E}$, 폴리페놀 등과 같은 천연 항산화물질들은 순환계 질병과 암 발생율을 감소시킨다고 보고된 바 있어[3,8], 자연에 널리 분포되어 있는 천연 항산화제의 개발 연구가 활발히 진행되고 있다.

근래에 단백질과 지방질을 보충하는데 우수한 대두(Glycine $\max$ L.)는 대표적인 식물성 단백질원으로써 saponin, phytic 
acid, isoflavones, hemaglutinins 등의 다양한 생리활성 물질 을 포함하고 있어 그 기능성에 대한 관심이 높아졌다[10]. 과거 대두를 이용한 전통발효식품들은 육류의 섭취량이 부족한 동 양에서는 중요한 단백질과 지방질의 공급원으로 고초균이 생 산하는 효소에 의해 단백질과 당질이 분해되어 끈끈한 점질물 이 형성되면서 특유의 맛과 냄새를 가지게 된다 $[14,23,26]$. 점 질물은 주로 glutamic acid로 이루어져 칼슘 흡수를 돕고 탁솔 이라는 항암 물질을 효율적으로 운반한다. 또한 노화 방지의 항산화 효과와 인슐린 분비를 원활히 하고 유산균 증식을 돕 고 콜레스테롤 수치를 떨어뜨린다[2]. 발효과정 중 분비되는 nattokinase는 fibrin을 강력하게 분해하는 효소로 밝혀지면서 혈전용해제로서 이용되며, 체중감소 및 혈압강하 효과 등을 나타내고 있다. 특히, 대두에 다량 함유된 isoflavone은 높은 항산화 효과 등 다양한 기능성을 지니고 있어 새로운 건강식 품으로써 관심이 모아지고 있다[11,25]. 한편, 황영현 등[5,13, 17]에 의해 새로이 육종 되어진 아가콩은 높은 질병 저항성과 isoflavone 함량을 지니고 있는 신품종 콩으로써 높은 항산화 활성 등을 가지고 있는 것으로 알려져 있다.

이에, 본 연구에서는 isoflavone의 함량이 일반 대두에 비해 높게 육종된 아가콩 3 호(노란 아가콩) 및 4 호(검정 아가콩)의 기능성을 조사하고자 혈전용해능이 우수한 Bacillus sp.의 선 별과 이를 활용하여 대두, 아가콩 3 호 및 4 호를 발효시켜 생산 된 점질물의 항산화 효과를 알아보았다.

\section{재료 및 방법}

\section{재료}

일반 대두(SB)는 시중에서 판매되는 것을 구입하여 사용 하였으며 육종 품종인 아가콩 3 호(노란 아가콩, $\mathrm{YA}$ )와 아가 콩 4 호 (검정 아가콩, $\mathrm{BA})$ 는 경북대학교에서 제 공받아 사용하 였다.

\section{발효 균주의 선별}

각각의 콩을 $20^{\circ} \mathrm{C}$ 의 물에 24 시간 동안 침지하여 건져낸 후 30 분간 물을 뺀 다음 $50 \mathrm{~g}$ 씩 담아 autoclave에서 30 분간 가압 증자하였다. 증자대두를 $50^{\circ} \mathrm{C}$ 이하로 냉각시킨 후 혈전 용해 능을 지닌 10 가지의 Bacillus sp. 균주 배양액을 증자대두의 $3 \%$ $(\mathrm{w} / \mathrm{w})$ 가 되도록 접종하고 $45^{\circ} \mathrm{C}$ 에서 72 시간 발효하였다. 발효 된 콩의 혈전용해능을 Fibrin plate method [2]로 측정하고 혈 전용해능이 가장 우수한 균주를 발효 균주로 사용하였다.

\section{발효콩 추출물의 제조}

Bacillus sp. sm26 균주를 이용하여 발효시킨 콩 발효물을 $70 \%$ ethanol로 추출한 후 여과(whatman paper No.2)하여 얻 어진 ethanol 추출액을 감압 농축하여 발효 대두 추출물 (FSBE), 발효 아가콩 3 호 추출물(FYAE), 발효 아가콩 4 호 추출
물(FBAE)를 각각 얻었으며 이를 본 연구의 시료로 사용하였다.

\section{총 페놀 함량 분석}

총 페놀 함량은 Singleton and Rossi method [27]을 이용하 여 Folin-Ciocalteu 시약이 페놀성 화합물에 의해 환원되어 몰 리브덴 청색으로 발색되는 원리를 이용하여 분석하였다. $\mathrm{FSBE}, \mathrm{FYAE}, \mathrm{FBAE} 40 \mathrm{mg}$ 씩을 각각 증류수 $1 \mathrm{ml}$ 에 녹인 후 96-microwell plate (Nunc, Roskilde, Denmark)에 $20 \mu \mathrm{l}$ 씩 분주하고 sodium carbonate $(0.7 \mathrm{M}) 80 \mu \mathrm{l}$ 를 혼합한 후 Folin-Ciocalteu regent (Folin-Ciocalteu:Water=1:10 v/v) 100 $\mu \mathrm{l}$ 첨가하여 15 분간 $37^{\circ} \mathrm{C}$ 에서 반응 후 microplate reader (Versa Max, USA)를 이용하여 $765 \mathrm{~nm}$ 에서 흡광도를 측정하 였다. 표준곡선은 gallic acid를 이용하여 작성한 표준곡선으로 총 페놀 함량을 계산하였다.

\section{총 단백질 및 당 함량 분석}

단백질 함량 측정은 Bio-rad사의 protein assay kit를 사용 하여 정량 하였다. 각 추출물의 농도가 $0.1 \sim 1.0 \mathrm{mg} / \mathrm{ml}$ 가 되도 록 증류수로 희석하고, 이 시료 $0.1 \mu 1$ 와 4 배 희석한 protein assay reagent $0.5 \mu \mathrm{l}$ 혼합하여 $25^{\circ} \mathrm{C}$ 에서 5 분간 방치한 후 595 $\mathrm{nm}$ 에서 흡광도를 측정하였다. 표준곡선은 BSA (bovine serum albumin) standard curve를 이용하여 작성한 표준곡선으 로 총 단백질 함량을 구하였다. 총 당 함량은 시료 $2 \mathrm{ml}$ 를 test tube에 넣고 5\% (v/v) phenol 수용액 $100 \mu 1$ 를 넣은 후 95\% 황산 $500 \mu 1$ 를 첨가하고 30 분 동안 실온에서 반응시킨 후 470 $\mathrm{nm}$ 에서 흡광도를 측정하였다. 표준곡은 glucose standard curve를 이용하여 작성한 표준곡선으로 총 당 함량을 구하였다.

\section{Free radical scavenging activity}

Free radical scavenging activity의 측정은 Brand-Williams method [4]을 이용하여 측정 하였다. $6 \times 10^{-5} \mathrm{M} \mathrm{DPPH}(1,1$ diphenyl-2-picrylhydrazyl) $\mathrm{MeOH}$ 용액 $195 \mu$ 와 증류수로 희 석한 추출물 $5 \mu \mathrm{l}$ 를 96-microwell plate에 혼합하였다 이때, 혼합용액 중의 추출물 최종 농도는 $1.0 \mathrm{mg} / \mathrm{ml}$ 가 되도록 하였 다. 실온에서 30 분간 방치한 후 $515 \mathrm{~nm}$ 에서 흡광도를 측정하 였고 기존의 항산화제로 알려진 BHA (butylated hydroxy anisole), BHT (butylated hydroxytoluene), ascobic acid를 대 조구로 사용하였다. 시료의 항산화 효능은 시료 무첨가구에 대한 시료 첨가구의 흡광도비로 산출하였다.

\section{Redcing power activity}

Reducing power activity의 측정은 Oyaizu method [22]을 이용하여 측정하였다. 시료 $50 \mu 1$ 에 Phosphate buffer (200 $\mathrm{mM}, \mathrm{pH}$ 6.6) $50 \mu \mathrm{l}$ 와 $1 \%$ potassium ferricyanide $50 \mu \mathrm{l}$ 를 넣고 $50^{\circ} \mathrm{C}$ 에서 20 분간 반응시켰다. 이때, 혼합용액 중의 추출물 최 종 농도는 $1.0 \mathrm{mg} / \mathrm{ml}$ 가 되도록 하였다. 반응 종료 후 반응액에 
$10 \%$ trichloroacetic acid 용액 $50 \mu 1$ 를 가하고 5,000 rpm에서 10 분간 원심분리 한 후 상등액을 $100 \mu \mathrm{l}$ 취하여 증류수 100 $\mu \mathrm{l}$ 와 $1 \%$ ferric chloride $20 \mu \mathrm{l}$ 을 혼합한 후 10 분간 반응시킨 뒤 $700 \mathrm{~nm}$ 에서 흡광도를 측정하였다.

\section{$\beta$-carotene-linoleic acid activity}

$\beta$-carotene-linoleic acid activity는 Miller method [20]을 이 용하여 측정하였다. $0.1 \mathrm{mg}$ 의 $\beta$-carotene을 chloroform 500 ul에 용해시킨 후 $20 \mathrm{mg}$ 의 linoleic acid 및 $100 \mathrm{mg}$ 의 Tween 40 을 첨가하여 $50^{\circ} \mathrm{C}$ 에서 chloroform을 감압 농축하여 제거하 고 얻어진 잔류물에 증류수 $50 \mathrm{ml}$ 를 가하여 정용한 것을 기질액 으로 사용하였다. 기질액 $10 \mu \mathrm{l}$ 와 시료 $200 \mu \mathrm{l}$ 를 96-microwell plate 가하여 혼합하였다. 이때, 혼합용액 중의 추출물 최종 농도는 $1.0 \mathrm{mg} / \mathrm{ml}$ 가 되도록 하였다. $50^{\circ} \mathrm{C}$ 에서 2 시간 반응시 킨 후 $470 \mathrm{~nm}$ 에서 흡광도를 측정하였으며, 시료의 항산화 효 능은 시료 무첨가구에 대한 시료 첨가구의 흡광도비로 산출하 였다.

\section{Hydrogen peroxide scavenging activity}

Hydrogen peroxide scavenging activity의 측정은 Miller method [21]을 이용하여 2,2-azinobis(3-ethylbenzthiazolin)-6sulfonicacid (ABTS)-peroxidase system에서 측정하였다. 96microwell plate에 시료 $80 \mu \mathrm{l}, 10 \mathrm{mM} \mathrm{H}_{2} \mathrm{O}_{2} 20 \mu \mathrm{l}$, phosphate buffer (pH 5.0, 0.1 M) $100 \mu 1$ 를 넣고 혼합하였다. 이때, 혼합용 액 중의 추출물 최종 농도는 $1.0 \mathrm{mg} / \mathrm{ml}$ 가 되도록 하였고 $37^{\circ} \mathrm{C}$ 에서 5분간 반응하였다. 반응액에 $1.25 \mathrm{mM}$ ABTS $30 \mu \mathrm{l}$ 와 1 $\mathrm{U} / \mathrm{ml}$ peroxidase $30 \mu 1$ 를 가하고 혼합한 후 $37^{\circ} \mathrm{C}$ 에서 10 분간 반응하여 $405 \mathrm{~nm}$ 에서 흡광도를 측정하였으며 시료의 항산화 효능은 시료 무첨가구에 대한 시료 첨가구의 흡광도비로 산출 하였다.

\section{결과 및 고찰}

\section{혈전용해효소 생산 균주의 선별 및 혈전용해 활성}

콩 발효물의 혈전용해효소 활성을 알아보기 위하여 동아대 학교 연구실에서 보관 중인 10가지 균주(Bacillus. sp LC-1, LC-3, LC-5, CKJ, \#15, \#18, \#20, \#38, BB-1, sm26)를 이용하여 대두콩(SB) 발효를 수행하였다. 그 결과, Fig. 1에 나타낸 것과 같이 Bacillus sp. sm26로 발효한 발효물의 혈전용해효소가 $4.80 \pm 0.3 \mathrm{unit} / \mathrm{ml}$ 로 가장 높은 혈전용해 활성을 나타내었고 이 결과를 토대로 Bacillus sp. sm26을 이용하여 YA 및 BA를 발효시키고 발효물의 혈전용해 활성을 조사하였다. 그 결과, $\mathrm{FYA}$ 에서는 $6.38 \pm 0.5 \mathrm{unit} / \mathrm{ml}, \mathrm{FBA}$ 에서는 $6.82 \pm 0.5 \mathrm{unit} / \mathrm{ml}$ 의 혈전용해 활성을 나타내었으며(Table 1) 이는 발효 대두인 $\mathrm{FSB}$ 에 비하여 각각 1.3 배와 1.4 배 높은 혈전용해 활성을 나타 내었다. 한편, FSB, FYA, FBA의 형태학적인 측면에서는 큰

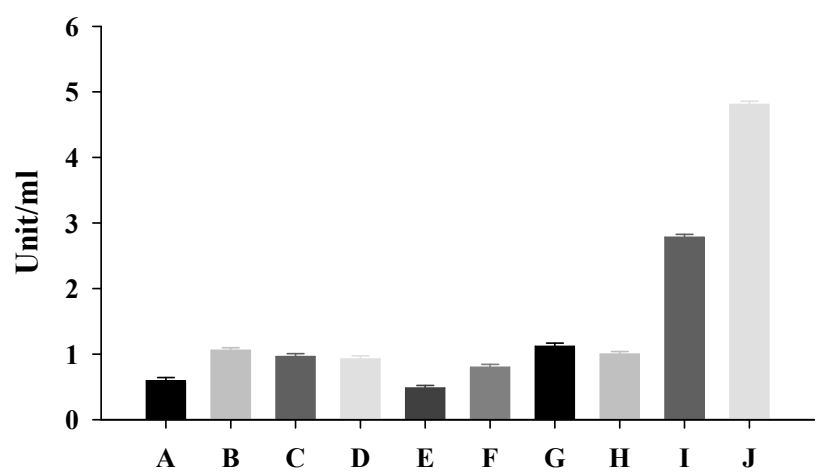

Fig. 1. Fibrinolytic activity of fermented soybeans by (A) Bacillus. sp LC-1, (B) Bacillus. sp LC-3, (C) Bacillus. sp LC-5, (D) Bacillus. sp CKJ, (E) Bacillus. sp \#15, (F) Bacillus. sp \#18, (G) Bacillus. sp \#20, (H) Bacillus. sp \#38, (I) Bacillus. sp BB-1 and (J) Bacillus. sp sm26. The results represents the means $\pm \mathrm{SE}$ and averages of triplicate experiments.

Table 1. Fibrinolytic activity of fermented beans by Bacillus. sp sm26

\begin{tabular}{cccc}
\hline & FSA & FYA & FBA \\
\hline Fibrinolytic activity $(\mathrm{U} / \mathrm{ml})^{\mathrm{a}}$ & $4.80 \pm 0.3$ & $6.38 \pm 0.5$ & $6.82 \pm 0.5$ \\
\hline
\end{tabular}

${ }^{\mathrm{a}}$ The results represents the means $\pm \mathrm{SE}$ and averages of triplicate experiments.

차이점을 나타내지 않았으며(Fig. 2) 특히 시판의 콩 발효물인 낫토와도 차이점은 발견되지 않아 아가콩이 혈전용해 효소의 생산적인 측면과 형태학적인 측면에서도 적합한 재료인 것으 로 사료된다.

\section{총 페놀, 단백질 및 당 햠량 분석}

페놀화합물은 구조식에 hydroxyl group을 소유하며, 공명 안정화된 구조로써 전자를 수용하는 기작으로 항산화능에 직 접적으로 기여한다[24]. 발효 추출물들의 총 단백질, 당, 페놀 함량의 정량 분석 결과는 Table 2 와 같다. 항산화 효능에 깊은 관여를 하고 있는 총 페놀 함량은 FYAE에서 $135.9 \pm 17.8 \mathrm{O}$ $\mathrm{g} / \mathrm{ml}$ 로 나타났으며 이는 FSBE보다 2배 높은 함량을 지니고 있는 것으로 나타났다. 총 단백질의 함량은 FYAE가 22.5 \pm 4.6 $\mathrm{g} / \mathrm{ml}$ 로, FSBE 보다 5 배 많은 단백질 함량을 보였다. 또한, 총 당 함량은 FBAE가 $108.9 \pm 25.3 \mathrm{~g} / \mathrm{ml}$ 로 FSBE보다 2배 많은 함 량을 나타내었다.

\section{Free radical scavenging activity}

추출물의 항산화 효능을 $\mathrm{DPPH}$ 에 대한 전자 공여능(electron donation ability, \%)으로 측정하였다. 전자공여작용은 활 성 라디칼에 전자를 공여하여 식품들의 지방 산화작용을 억제 하는 하고, 생체에서는 활성 라디칼에 의한 세포 손상과 노화 

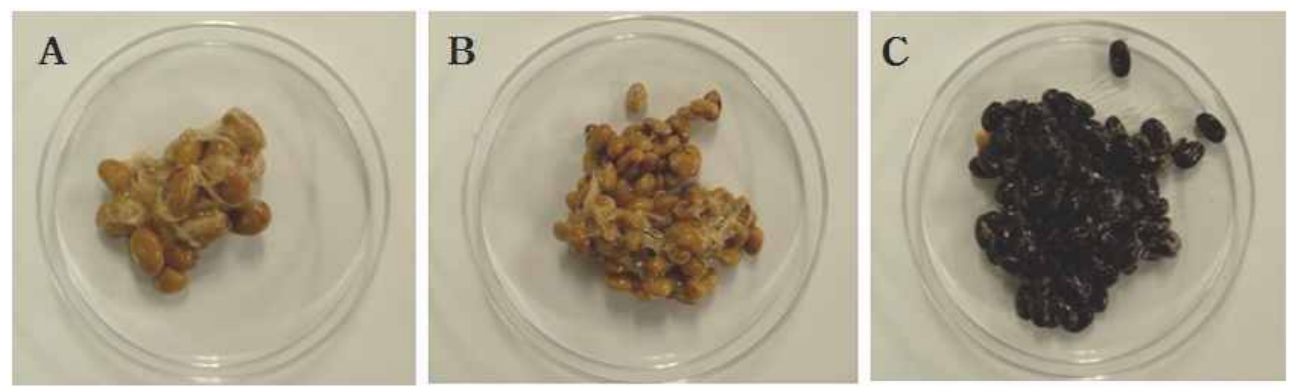

Fig. 2. Morphological appearance of FSB (A), FYA (B) and FBA (C).

Table 2. Total phenolic, protein and sugar contents of $70 \%$ ethanol extract of fermented beans

\begin{tabular}{lccc}
\hline & FSBE & FYAE & FBAE \\
\hline Total phenolic content $(\mathrm{mg} / \mathrm{g})^{\mathrm{a}}$ & $1.58 \pm 0.31$ & $3.40 \pm 0.44$ & $2.45 \pm 0.20$ \\
Total protein content $(\mathrm{mg} / \mathrm{g})^{\mathrm{b}}$ & $0.12 \pm 0.04$ & $0.56 \pm 0.11$ & $0.39 \pm 0.12$ \\
Totla sugar content $(\mathrm{mg} / \mathrm{g})^{\mathrm{c}}$ & $1.46 \pm 0.27$ & $2.41 \pm 0.48$ & $2.72 \pm 0.63$ \\
\hline
\end{tabular}

${ }^{a}$ The results represents the means $\pm \mathrm{SE}$ and averages of triplicate experiments and the values were mean \pm SE analyzed using gallic acid as a standard.

${ }^{b}$ The results represents the means \pm SE and averages of triplicate experiments and the values were mean \pm SE analyzed using BSA (bovine serum albumin) as a standard.

${ }^{c}$ The results represents the means $\pm \mathrm{SE}$ and averages of triplicate experiments and the values were mean $\pm \mathrm{SE}$ analyzed using glucose as a standard.

를 억제한다[12,16]. 추출물의 DPPH radical scavenging 활성 의 결과는 Fig. 3 와 같다. 추출물의 DPPH radical scavenging 활성은 농도의존적으로 농도의 증가에 따라 활성도 증가하였 고 $\mathrm{FBAE}$ 의 농도가 $1 \mathrm{mg} / \mathrm{ml}$ 일 때 $79 \%$ 로 가장 높게 나타났으 며 FYAE도 $57 \%$ 로 나타나 FSB에 비해 최대 2배 가량 높게 나타났다. 대조구로 사용된 gallic acid, BHA, BHT의 경우, 추 출물과 동일하게 $1.0 \sim 0.1 \mathrm{mg} / \mathrm{ml}$ 의 농도로 측정하였을

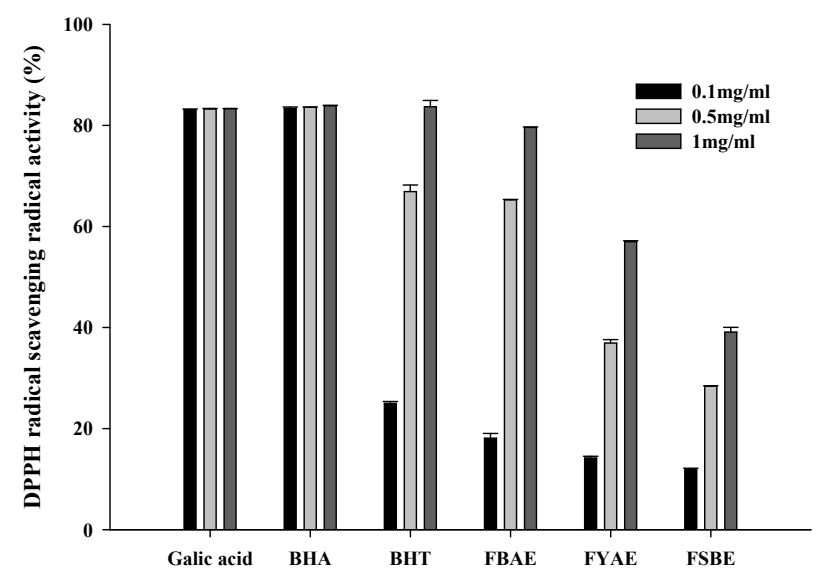

Fig. 3. DPPH radical scavenging activity of $70 \%$ ethanol extract of fermented beans. BHA: butylated hydroxy anisole, BHT: butylated hydroxytoluene, FBAE: fermented black agabean, FYAE: fermented yellow agabean, FSBE: fermented soybean. The results represents the means $\pm \mathrm{SE}$ and averages of triplicate experiments.
때, gallic acid와 BHA는 모든 농도에서 $83 \%$ 이상의 높은 활성 을 나타내었고, BHT는 $1 \mathrm{mg} / \mathrm{ml}$ 의 농도에서 $83 \%$ 의 활성을 보였으나 농도가 낮아질수록 그 활성이 다른 대조구에 비해 급격히 낮아졌다.

\section{Reducing power activity}

활성 산소종 및 유리기에 전자를 공여하는 능력인 환원력은 항산화능과 밀접한 관련이 있는 것으로 알려져 있는데 이는 항산화 활성에 주요한 인자로 작용한다. 일반적으로 환원력이 큰 것일수록 전자공여능이 높다고 알려져 있고 전자공여능은 phenol성 물질에 대한 항산화 효능의 지표라고 할 수 있다. 발효 콩 추출물의 환원력을 Fig. 4 에 나타내었다. 추출물의 농 도가 높아질수록 환원력은 증가하였으며, $1 \mathrm{mg} / \mathrm{ml}$ 의 농도에 서 $\mathrm{FBAE}$ 가 $0.85 \pm 0.23$ 로 가장 높은 환원력을 나타내었으며 이 는 대조구와 비슷한 환원력을 보였다. 또한, FYAE도 $0.55 \pm 0.42$ 로 FSB의 $0.45 \pm 0.11$ 보다 높게 나타났다. 그러나 추출물의 농도 가 줄어들수록 대조구에 비해 농도 의존력이 떨어지며 환원력 은 감소하는 것으로 나타났다.

\section{$\beta$-Carotene-linoleic acid activity}

추출물의 지질과산화 억제능을 $\beta$-carotene이 함유된 linoleic acid emulsion계에서 측정하였다(Fig. 5). 모든 추출물들 이 농도에 의존적인 지질과산화 억제능을 지니고 있었고 특히 $\mathrm{FBAE}$ 의 경우에는 대조구인 galic acid, BHA와 비교하여 지질 과산화 억제능이 대등하게 나타났으며 $1 \mathrm{mg} / \mathrm{ml}$ 의 농도에서 


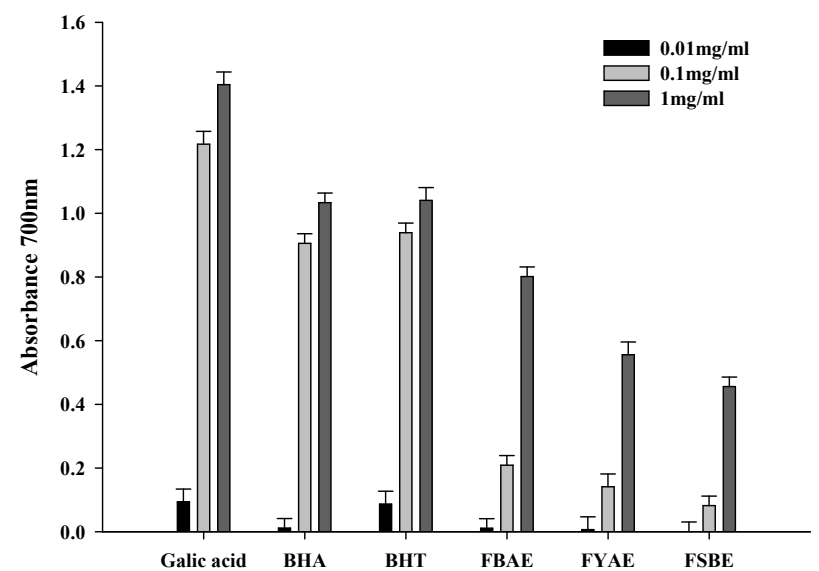

Fig. 4. Reducing power activity of $70 \%$ ethanol extract of fermented beans. The abbreviations were shown in Fig. 3. The results represents the means $\pm \mathrm{SE}$ and averages of triplicate experiments.

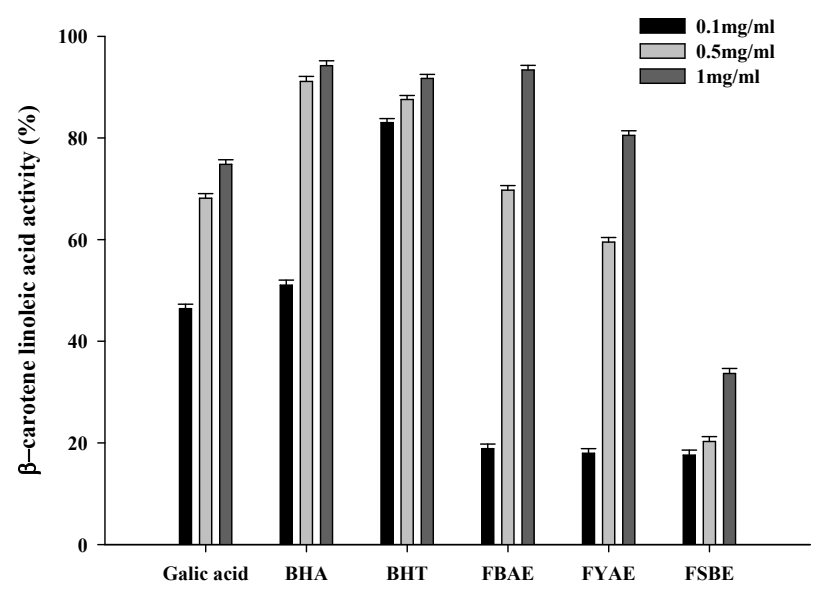

Fig. 5. B-Carotene-linoleic acid activity of 70\% ethanol extract of fermented beans. The abbreviations were shown in Fig. 3. The results represents the means $\pm S E$ and averages of triplicate experiments.

93\%로 galic acid와 BHT보다 높게 나타났다. 또한 FSBE와 비 교하면 $\mathrm{FBAE}$ 가 $\mathrm{FSBE}$ 보다 3 배 정도 높은 활성을 나타냈고 FYAE는 2.5배 높은 활성을 나타내었다. 생체 내에서 $\mathrm{Fe}$ 과 같 은 금속류는 과산화수소와 빠르게 반응하여 hydroxyl radical 을 형성함으로써 2차 산화가 진행되는데, 세포막의 지질과산 화 반응이 radical에 의해 진행되고 생체 내 DNA의 손상까지 초래한다는 것을 볼 때[6], hydroxyl radical 소거 및 지질과산 화 억제능이 우수한 FBAE와 FYAE는 2차 산화물의 생성억제 제로 유효할 것으로 사료된다.

\section{Hydrogen peroxide activiy}

과산화수소에 대한 추출물의 소거능 효과를 Fig. 6에 나타 내었다. Hydrogen peroxide $\left(\mathrm{H}_{2} \mathrm{O}_{2}\right)$ 는 세포에 대하여 독성물

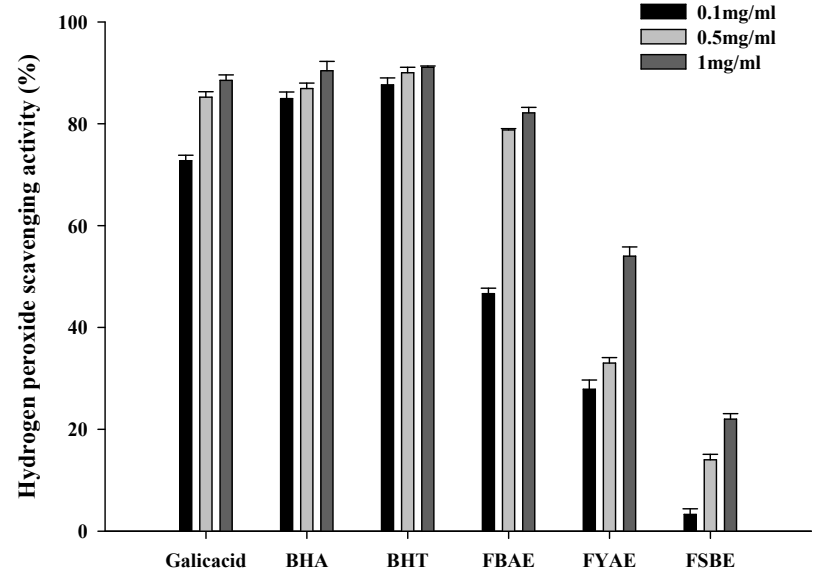

Fig. 6. Hydrogen peroxide scavenging activity of $70 \%$ ethanol extract of fermented beans. The abbreviations were shown in Fig. 3. The results represents the means \pm SE and averages of triplicate experiments.

질로 작용하며 전이 금속이온과 함께 활성산소 종들을 생산하 며[21], 체내의 항산화 방어효소들의 작용으로 물로 전환되어 분해된다. 추출물의 $1 \mathrm{mg} / \mathrm{ml}$ 농도에서는 $\mathrm{FBAE}$ 가 $82 \%$ 로 이는 $\mathrm{FSBE}$ 와 비교해 4 배 높은 효과를 나타내었으며 FYAE의 경우 에도 FSBE보다 2.5배 높은 효과를 나타내어 FSBE에 비해 과산 화수소 소거능이 뛰어 났으며 농도 의존적으로 활성의 증가를 나타내었다. 또한, galic acid, BHA, BHT와 과산화수소 제거 효과를 비교하였을 때 $\mathrm{FBAE}$ 의 경우 그 효과가 높은 농도에서 대조구와 비슷한 효과를 나타내었다.

이상의 결과에서 기능성 콩 발효물인 FYA와 FBA는 FSB에 비하여 높은 혈전용해 활성을 나타내었으며 발효 콩 추출물인 FYAE와 FBAE도 FSBE에 비하여 높은 항산화 효능을 지니고 있었다. 특히, FBAE는 FYAE에 비하여 항산화 효능에 깊은 영향을 미치는 총 페놀성 화합물의 함량이 적었음에도 월등한 항산화 효능을 나타내고 있음을 알 수 있었다. 이는 $\mathrm{FBAE}$ 에 존재하는 안토시아닌이 항산화 효능에 영향을 미치고 있는 것으로 사료되며 앞으로 아가콩을 이용한 발효물이 좋은 천연 항혈전과 항산화 식품으로서 높은 이용 가능성을 시사하였다.

\section{감사의 글}

본 논문은 농림부 농림기술개발사업의 지원(307003-03-1HD140)에 의하여 이루어진 결과의 일부입니다.

\section{References}

1. Aischer, R. G. and J. L Hess. 1993. Antioxidants in higher plants. CRC Press, Boca Raton. 1-17.

2. Astrup, T. and S. Mullertz. 1952. The fibrin plate method for estimating fibrinolytic activity. Arch Biochem Biophys. 40, 
346-351.

3. Block, G., B. Paterson, and A. Subar. 1992. Fruits, vegetables and cancer prevention:a review of the epidemiological evidence. Nutr. Cancer 18, 1-29.

4. Brand-Williams, W., M. E. Cuvelier, and C. Berset. 1995. Use of a free radical method to evaluate antioxidant activity, Lebensmittel-Wissenschaft und -Technologie. Food Sci. Technol. 28, 25-30.

5. Choi, K. U., H. S. Ryu, H. T. Kim, S. M. Kim, S. J. Lee, J. D. Choi, Y. H. Hwang, S. Y. Choi, and O. S. Kwon. Protemic Characterization of the of 'Agakong', a Small-seeded Recombinat Inbred Line Derved from 'Eunhakong' (Glycine max) x'KLG10084'(Glycine soja). 2008. Food Sci. Biotechnol. 17, 912-918.

6. Choi, S. I., Y. M. Lee, and T. R. Heo. 2003. Screening of hyaluronidase inhibitory and free radical scavenging activity in vitro of traditional herbal medicine extracts. Korean J. Biotechnol. Bioeng. 18, 282-288.

7. Cutler, R. G. Antioxidants aging, and longevity. 1984. pp. 371-423, 6th eds., In Pryor, W. A. (ed.), Free Radicals in Biology. Academic press.

8. Diplock, A. T., J. L, Charleux, G. Crozier-Willi, F. J. Kok, C. Rice-Evans, M. Roberfroid, W. Stahl, and J. Vina-Ribes. 1998. Functional food science and defence against reactiveoxidative species. Brit. J. Nutr. 80, 77-112.

9. Fang, Y. Z., S. Yang, and G. Wu. 2002. Free radicals, antioxidants, and nutrition. Nutrition 18, 872-879.

10. Heo, S., S. K. Lee, and H. K. Joo. 1998. Isolation and identification of fibrinolytic bacteria from Korean traditional Chungkookjang. Agric. Chem Biotechnol. 41, 119-124.

11. Hermann, K. 1989. Occurrence and content of hydroxycinnamic and hydroxyl-benzoic acid compounds in foods. Crit. Rev. Food Sci. Nutr. 28, 315-347.

12. Jeong, D. S., Y. K. Sohn., Y. I. Lee., I. H. Yun, and J. K. Kim. 1986. Study on the chemical constituents and processings of Ganoderma lucidum. Annual Research Report 28, 140-148.

13. Ku, K. M., M. G. Kim, M. J. Hong, Y. S. Heong, J. S. Kim, I. J. Lee, D. H. Shin, Y. H. Hwang, and Y. H. Kang. 2009. Antioxidant and QR inductive activities of novel functional soybean 'Agakong3'. Food Sci. Biotechnol. 18, 624-629.

14. Lee, B. Y., D. M. Kim, and K. H. Kim. 1991. Physico-chemical properties of viscous substance extracted from
Chungkukjang. Korean J. Food Sci. Technol. 23, 599-604.

15. Lee, H. J., S. I. Kim, J. G. Park, J. N. Park, I. J. Han, B. S. Song, J. H. Kim, M. W. Byun, and J. W. Lee. 2008. Effect of Choi-cha on fermentation characteristics and sensory quality of chungkookjang (Korean fermented soybean). Korean J. Food Preserv. 15, 144-149.

16. Lee, K. D., H. K. Chang, and H. K. Kim. 1997. Antioxidative and nitrite scavenging activities of edible mushrooms. Korean J. Food Sci. Technol. 29, 432-436.

17. Lee, J. D., Y. H. Yoon, I. K. Chumg, S. K. Park, and Y. H. Hwang. 2005. A New Glycine soja Germplasm Accession with Green Seed-coat Color. Breeding Sci. 55, 21-25

18. Lee, J. H. and D. B. Min. 2006. Nutraceuticals, aging, and food oxidation. In Handbook of Functional Lipids. Taylor \& Francis Group, LLC, CRC Press, USA. 325-350.

19. Masaki, H., S. Sakaki, T. Atsumi, and H. Sakurai. 1995. Active-oxygen scavenging activity of plant extract. Biol. Pharm Bull. 18, 162-166.

20. Miller, H. E. 1971. Simplified method for the evaluation of antioxidants. J. American Oil Chemists' Society 48, 91.

21. Obata, T. and Y, Yamanaka.1996. Effect of iron (II) on thegeneration of hydroxyl free radicals in rat mycocardium. Biochem Pharmaco. 151, 1411-1413.

22. Oyaizu M. 1985. Studies on products of browning reaction prepared from glucoseamine. Jpn J. Nutr. 44, 307-314

23. Park, C., Y. H. Chol, H. J. Shin, H. Poo, J. J. Song, C. J. Kim, and M. H. Sung. 2005. Effect of high-molecular-weight poly- $\gamma$-glutamic acid from Bacillus subtilis (chungkookjang) on Casolubility and intestinal absorption. J. Microbiol. Biotechnol. 15, 855-858.

24. Rice-Evans, P. and C. Haynes. 1995. Positronium formation and the phases of two-dimensional oxygen physisorbed on graphite. Phys. Rev. B Condens Matter 52, 17439-17442.

25. Sumi, H., H. Hamada, H. Tsushima, H. Mihara, and H. Muraki. 1987. A novel fibrinolytic enzyme (nattokinase) in the vegetable cheese Natto; a typical and popular soybean food in the Japanese diet. Experientia 43, 1110-1111.

26. Tanimoto H., M. Mori, M. Motoki, K. Torii, M. Kadowaki, and T. Noguchi. 2001. Natto mucilage containing poly- $\gamma$ -glutamic acid increases soluble calcium in the rat small intestine. Biosci Biotechnol. Biochem 65, 516-521.

27. Solbakken, A. M., G. Rørbakken., and T. Gundersen. 1997. Nature medicine as intoxicant. Tidsskr Nor. 117, 1140-1141. 
초록 : Bacillus sp.에 의하여 발효된 신품종 아가콩 발효 산물의 혈전 용해 활성 및 항산화 효과

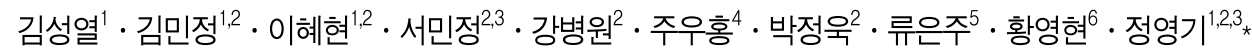

( ${ }^{1}$ 동아대학교 생명과학과, ${ }^{2} \mathrm{Medi}-\mathrm{Farm}$ 산업화 연구사업단, ${ }^{3}$ 동아대학교 의생명과학과, ${ }^{4}$ 창원대학교 생물학 과, ${ }^{5}$ 한서대학교 피부미용학과, ${ }^{6}$ 경북대학교 식물생명과학부)

본 연구에서는 혈전용해능이 우수한 Bacillus sp. sm26을 선별하고 신품종 기능성 콩인 노란 아가콩(YA)와 검 정 아가콩 $(\mathrm{BA})$ 을 발효시킨 발효콩(FYA, $\mathrm{FBA})$ 의 혈전용해 활성과 $70 \%$ ethanol 추출(FYAE, $\mathrm{FBAE})$ 에 대한 항산화 효능을 조사하였다. FYA와 $\mathrm{FBA}$ 의 혈전용해 활성은 각각 $6.38 \pm 0.5$ 와 $6.83 \pm 0.5 \mathrm{U} / \mathrm{ml}$ 로 대두 발효물(FSB)보다 각 각 1.3 배와 1.4 배 높은 것으로 나타났다. 총 페놀 함량은 FYAE와 FBAE가 각각 $3.40 \pm 0.44 \mathrm{mg} / \mathrm{g}, 2.45 \pm 0.20 \mathrm{mg} / \mathrm{g}$ 으로 나타나, 대두 발효 추출물(FSBE)에 비하여 약 2 배 이상의 높은 페놀 함량을 나타내었다. FYAE의 총 단백질 과 총 당 함량은 각각 $0.56 \pm 0.11 \mathrm{mg} / \mathrm{g}$ 과 $2.41 \pm 0.48 \mathrm{mg} / \mathrm{g}$ 이었으며 FYBA는 각각 $0.39 \pm 0.12 \mathrm{mg} / \mathrm{g}$ 과 $2.72 \pm 0.63$ $\mathrm{mg} / \mathrm{g}$ 으로 나타나, FYAE가 FSBE보다 각각 4.7 배와 1.7 배 높은 총 단백 질과 총 당 함량을 지닌 것으로 나타났다. $\mathrm{DPPH}$ radical 소거능은 FBAE가 $1 \mathrm{mg} / \mathrm{ml}$ 에서 $79 \%$ 로 가장 높게 나타났으며 2배 높은 활성을 나타내었다. 환원 력은 $\mathrm{FBAE}$ 가 $1 \mathrm{mg} / \mathrm{ml}$ 의 농도에서 가장 높은 환원력을 나타내었으며 FSBE에 비해 2배 높은 활성을 보였다. 지 질 과산화능은 $1 \mathrm{mg} / \mathrm{ml}$ 일 때 $\mathrm{FBAE}$ 는 $93 \%$ 로 $\mathrm{FSBE}$ 의 약 3 배 높은 활성을 나타내었고 $\mathrm{FYAE}$ 또한 $80 \%$ 로 2.5 배 높은 활성을 보였다. 과산화 수소에 대한 소거능은 $1 \mathrm{mg} / \mathrm{ml}$ 농도에서는 $\mathrm{FBAE}$ 가 $82 \%$ 로 FSBE에 비해 4 배 높은 효과를 나타내고 FYAE의 경우 2.5 배 높은 효과를 나타낸다. 이상의 연구 결과에서, 기능성 콩인 아가콩 발효물의 혈전용해 활성과 항산화 효능은 일반 콩에 높게 나타났으며 이는 앞으로 새로운 천연 기능성 식품으로서의 이용 가능성을 시사하고 있다. 